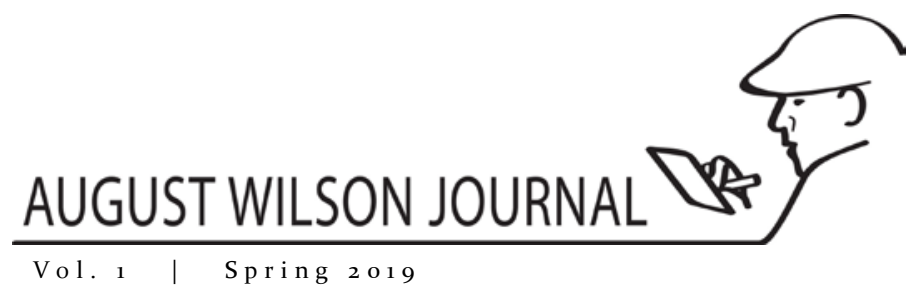

\title{
Dramaturg Interview: Soyica Colbert on Two Trains Running
}

\author{
By Melonnie Walker \\ Dramaturg and Social Media Coordinator for the August Wilson Society
}

In Two Trains, we found that Wilson's grappling with questions about self-determination and justice at the heart of the black power and black arts movements continue to inform political and artistic organizations today.

- Soyica Colbert

\begin{abstract}
An interview with Soyica Colbert, dramaturg for Arena Stage's (Washington, D.C.) production of Two Trains Running.

Keywords

August Wilson, Arena Stage, Washington, D.C., Two Trains Running, Pittsburgh, Hill District, Dramaturgy, Broadway, Soyica Colbert
\end{abstract}

In the spring of 2018, Arena Stage in Washington, DC, collaborated with Seattle Repertory Theatre to co-produce Two Trains Running in DC. The run was originally scheduled for March 30 through April 29, but, due to its success, was extended through May 6 , 2018. The production was directed by Juliette Carrillo and the production dramaturg was Dr. Soyica Colbert.

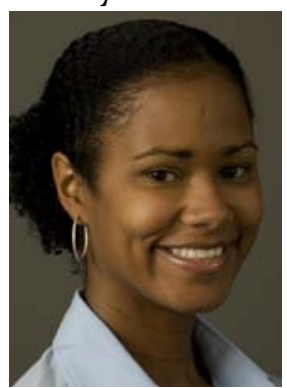

Soyica Cobert

This play is August Wilson's seventh installment in his ten-play American Century Cycle, premiering on Broadway in 1992. The play is set in 1969 in a neighborhood diner that serves as a gathering place for residents of Pittsburgh's Hill District. Contextually, the backdrop for this play is the turbulent decade of the 196os, which encompassed race riots, the ongoing Vietnam War, the March on Washington, and the assassinations of John F. Kennedy, Malcolm X, and Martin Luther

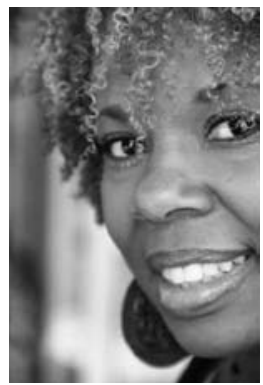

Mel Walker King, Jr. Through the characters in this play, Wilson

explores themes of unity and pride, contrasting life principles, and how communities and individuals choose to create their path forward.

I interviewed Dr. Colbert about her process for this production of Two Trains Running, and asked her to share her experience working with the cast and crew. I was 
\begin{tabular}{l|ll} 
Vol.1 & Spring 2019
\end{tabular}

specifically interested in any challenges, surprises, or special requests that may have occurred.

MW: What kind of research goals did the director provide for you? Such as certain historical context, or certain script references, etc.

SC: In consultation with the Artistic team at Seattle Repertory Theatre, we provided research about August Wilson's Century Cycle, Two Trains Running's place in the cycle, Pittsburgh in the 1960s, Gentrification, the Civil Rights Movement, the Black Power Movement, and the Black Arts Movement.

MW: Were there any particular challenges or surprises that came up during the process?

SC: The main question we returned to again and again was how the questions of the play resonate with contemporary issues. In Two Trains, we found that Wilson's grappling with questions about self-determination and justice at the heart of the black power and black arts movements continue to inform political and artistic organizations today.

MW: Do you have a favorite scene or section of dialogue from Two Trains Running?

SC: There are several powerful moments. My favorite line is when Memphis says, "Freedom is heavy. You got to put your shoulder to freedom. Put your shoulder to it and hope your back hold up." The moments of intimacy between Sterling and Risa are also striking because they point to political collaboration emerging by way of friendship and trust.

MW: Can you tell our readers about other relevant events that took place around 1969, when this play is set, that may have influenced the characters, or even the playwright?

SC: In June 1966, Carmichael declared that "1966 [was] the year of the concept of Black power." Soon after, SNCC, headed by Stokely Carmichael, rejected its historical strategy of nonviolence and embraced the notion of Black Power which emphasized Black nationalism and self-reliance. This led to the decline of interracialism within the organization. On October 15, 1966, in the wake of the assassination of Malcolm X, Huey P. Newton and Bobby Seale founded the Black Panther Party for Self-Defense in West Oakland, California. In 1968, Wilson co-founded the Black Horizon Theater Company with friend Rob Penny in the Hill District of Pittsburgh. Martin Luther King, Jr. was assassinated in 1968. As we note in the dramaturgical workbook, the Black Power Era was the time period when Wilson came of age as an artist. As a result, this play is not only a reflection on the decade but also the contexts that formed him as an artist.

MW: Did you have any personal revelations about the play as you were researching it?

SC: It is striking how play resonates so profoundly with ongoing questions about spatial justice and gentrification in Washington D.C.

MW: During your interactions with the cast and crew, what were the definitive themes about Two Trains Running that you felt a need to emphasize, or particular ideas that you wanted to highlight?

SC: Because we worked on the notebook for the Seattle Rep. production first, we did not have much opportunity to interact with the cast and crew for that production. We did enjoy 
W A L K E R: D R A M A T U R G I T E R V I E W : S O Y I C A C O L B E R T O N T W O TR A I N S R U N N IN G

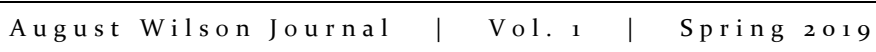

collaborating with the literary managers at Seattle Rep and Arena Stage to develop the workbook and respond to questions from the artistic teams.

MW: In scheduled talkbacks, or engaging with the audience, what can you tell our readers about audience response?

SC: In a talkback at Arena Stage, two of the student research assistants, Skylar Luke and Taurjhai Purdie, answered questions about the play and its history. It was useful to hear how audiences responded to the politics of the play and to the way it foreshadows many of ongoing struggles of urban America regarding corporatization of businesses and segregation."

MW: Are there any other plays in August Wilson's American Century Cycle that you have served as dramaturg for, or would like to?

SC: I have not served as a dramaturg on any of Wilson's other plays but would welcome the opportunity.

MW: Thank you so much for sharing your experiences with us.

Dr. Soyica Colbert is the Chair of the Department of Performing Arts, Director of Theater and Performance Studies and an Associate Professor of African American Studies and Theater and Performance Studies at Georgetown University. She is the author of The African American Theatrical Body: Reception, Performance and the Stage (Cambridge UP, 2011) and Black Movements: Performance and Cultural Politics (Rutgers UP, 2017). Dr. Colbert has published articles and essays in American Theatre, African American Review, and the collection of essays edited by Alan Nadel, entitled, August Wilson: Completing the Twentieth-Century Cycle.

\section{Works Cited}

Wilson, August. Two Trains Running. Theatre Communications Group. 2007.

\section{Author Bio}

Ms. Melonnie Walker is a dramaturg and social media coordinator for the August Wilson Society.

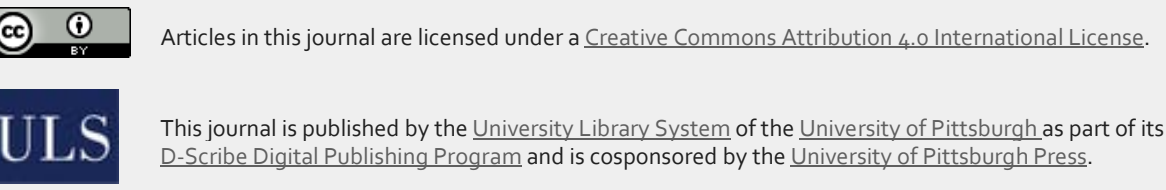

